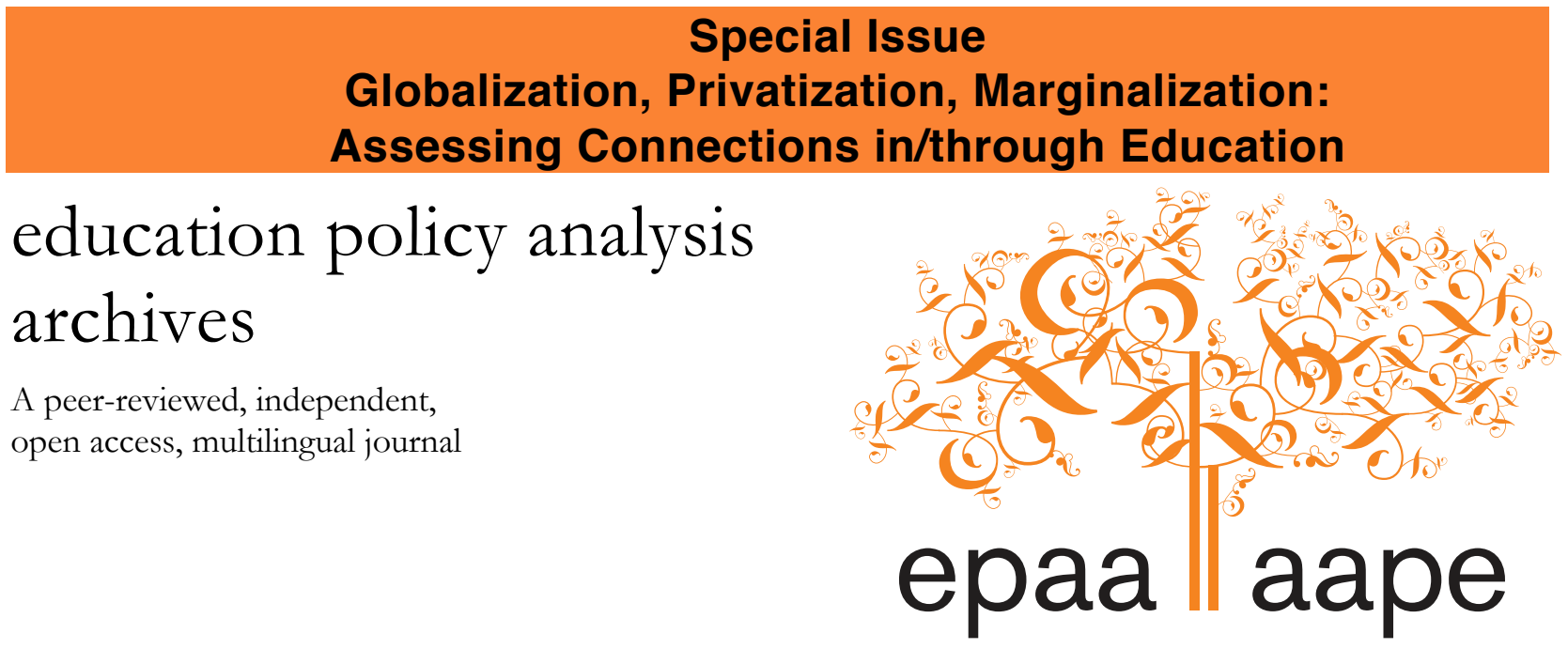

Arizona State University

\title{
Motivations to Set Up and Manage Low-fee Private Schools in India
}

\author{
Hannah Mond \\ \& \\ Poorvaja Prakash \\ Teachers College, Columbia University \\ United States
}

Citation: Mond, H., \& Prakash, P. (2019). Motivations to set up and manage low-fee private schools in India. Education Policy Analysis Archives, 27(134). https://doi.org/10.14507/epaa.27.4361 This article is part of a special issue, Globalization, Privatization, Marginalization: Assessing Connections in/through Education, Part 2, guest edited by D. Brent Edwards and Alex Means.

Abstract: Low-fee private schools (LFPS) educate some of India's poorest children. They have grown dramatically over the last decade in India and have changed the country's educational landscape (Srivastava, 2016), yet there is little conclusive evidence that the schools significantly help their students. Our study aims to better understand why and how the schools have grown, and we use a social entrepreneurship theory - the push and pull theory - to guide our research questions. We interviewed eight owners and asked: "what are the motivations of individual actors in setting up low fee private schools?" and "how do these actors justify continuing their work when presented with empirical research on these schools' mixed impact on the quality of education they provide? There were more pull than push factors. Owners' distrust of government schools, and the characteristically low-income nature of the communities drove them to choose the low-fee private school model. They justified their work despite evidence of these schools' mixed impact, arguing that Journal website: http://epaa.asu.edu/ojs/ Facebook: /EPAAA

Manuscript received: 11/6/2018 Twitter:@epaa_aape 
their schools were different from the regular LFPS and that there is high parental support for their schools. We recommend policies to better support such individuals and provide them with an awareness of alternative paths to contribute to improving education.

Keywords: Low fee private school; motivation; social entrepreneur; push-and-pull; marginalization; privatization; low-income; growth

\section{Motivaciones para establecer y administrar escuelas privadas de bajo costo en la India}

Resumen: Las escuelas privadas de bajo costo (LFPS) educan a algunos de los niños más pobres de la India. Han crecido dramáticamente en la última década en India y han cambiado el panorama educativo del país (Srivastava, 2016), sin embargo, hay poca evidencia concluyente de que las escuelas ayuden significativamente a sus estudiantes. Nuestro estudio tiene como objetivo comprender mejor por qué y cómo han crecido las escuelas, y utilizamos una teoría de emprendimiento social, la teoría de empujar y tirar, para guiar nuestras preguntas de investigación. Entrevistamos a ocho propietarios y les preguntamos: “¿Cuáles son las motivaciones de los actores individuales para establecer escuelas privadas de bajo costo?" y "¿Cómo justifican estos actores continuar su trabajo cuando se les presenta una investigación empírica sobre el impacto mixto de estas escuelas en la calidad de la educación? ¿ellos proveen? Hubo más factores de atracción que de empuje. La desconfianza de los propietarios de las escuelas gubernamentales, y la naturaleza característicamente de bajos ingresos de las comunidades los llevó a elegir el modelo de escuela privada de bajo costo. Justificaron su trabajo a pesar de la evidencia del impacto mixto de estas escuelas, argumentando que sus escuelas eran diferentes de las LFPS regulares y que existe un alto apoyo de los padres para sus escuelas. Recomendamos políticas para apoyar mejor a esas personas y proporcionarles una conciencia de caminos alternativos para contribuir a mejorar la educación.

Palabras-clave: Escuela privada de bajo costo; motivación; emprendedor social; push-andpull; marginación; privatización; de bajos ingresos; crecimiento

\section{Motivações para estabelecer e administrar escolas particulares de baixo custo na Índia}

Resumo: Escolas particulares de baixo custo (LFPS) educam algumas das crianças mais pobres da Índia. Eles cresceram dramaticamente na última década na Índia e mudaram o cenário educacional do país (Srivastava, 2016), mas há poucas evidências conclusivas de que as escolas ajudem significativamente seus alunos. Nosso estudo tem como objetivo entender melhor por que e como as escolas cresceram e usamos uma teoria do empreendedorismo social - a teoria do empurra e empurra - para orientar nossas perguntas de pesquisa. Entrevistamos oito proprietários e perguntamos: "quais são as motivações de atores individuais na criação de escolas particulares de baixo custo?" E "como esses atores justificam a continuidade de seu trabalho quando apresentados com pesquisas empíricas sobre o impacto misto dessas escolas na qualidade da educação eles providenciam? Havia mais fatores de atração do que de pressão. A desconfiança dos proprietários em relação às escolas públicas e a natureza caracteristicamente de baixa renda das comunidades os levaram a escolher o modelo de escola particular de baixo custo. Eles justificaram seu trabalho, apesar das evidências do impacto misto dessas escolas, argumentando que suas escolas eram diferentes do LFPS regular e que existe um alto apoio dos pais para suas escolas. Recomendamos políticas para apoiar melhor esses indivíduos e proporcionar a eles um caminho alternativo para contribuir para melhorar a educação.

Palavras-chave: escola particular de baixa taxa; motivação; empreendedor social; push-andpull; marginalização; privatização; baixa renda; crescimento 


\section{Motivations to Set Up and Manage Low-fee Private Schools in India}

Low-fee private schools (LFPS) are non-government schools that cater to children from lowincome families and that operate at a fraction of a cost of a typical government school. There is no clear-cut definition of low-income, and in our study it refers to how the LFPS owners described the communities in which they serve - marginalized communities with few resources where children are often made to work to help support their families. LFPS' increasing prevalence is a global phenomenon - their numbers have grown significantly in Kenya, the Philippines, Liberia, Pakistan, Sri Lanka and India (Ashley et al., 2014) and there are discussions about them opening in the UK (Tooley, 2018). Initially known as "mom and pop" stores (Srivastava, 2016), the phenomenon has now expanded to chain schools, creating an opportunity for several types of international funders to support the schools. These international actors, such as international organizations (DFID), venture capitalists (Omidyar) and companies (Facebook) (Global Initiative for Economic, Social and Cultural Rights, 2018), have played a significant role in promoting LFPS. By funding these schools, these actors have facilitated their expansion, thus demonstrating the increasing political and economic globalization of the phenomena. It is clear that LFPS are now extremely influential around the world and it is important that academics and practitioners alike continue to learn more about such schools. While there is plenty of research on the rise and impact of such schools, little research has focused on the individuals who have set up the schools.

Our paper fills this gap in the LFPS literature - research on LFPS globally and in India focuses on macro factors to explain their growth, and predominantly discusses notions of equity, quality and academic outcomes (Ashley et al., 2014; Baird, 2009; Chattopadhay \& Roy, 2017; Härmä, 2011). Thus far literature tells us that a growing space has been created for LFPS predominantly because of the perceived failure of government schools (Härmä, 2011; Kingdon, 2017), and the need to increase access and quality to all students. The aforementioned scholars almost unanimously agree that there is a strong correlation between the perceived 'problem' - the failure of government schools to provide a quality education to all children, and the supposed 'solution' - low-fee private schools. In low-fee private school literature, critics discuss the negative impact on equity and affordability, the limited evidence that low-fee private school students outperform government school students, and the challenges they face, such as the lack of qualified teachers (Riep, 2017; Srivastava, 2016).

Little research, however, focuses on the individuals who have set up these schools, which is important to fully understand the rise of LFPS. Interviewing these actors may help explain why these schools exist and how they continue to grow despite the mounting evidence of their limitations. This paper primarily intends to give an insight into the frequently unmentioned voices of some of the individuals who have enabled LFPS to be created and sustained. Through our analysis of the findings we will discuss how the individuals' motivations to set up LFPS impact on marginalized communities, and reflect the globalization of privatization in education. We also suggest certain policy recommendations from our findings that address the equity concerns from the expansion of such schools. Our research questions are:

- What are the motivations of individual actors in setting up low fee private schools?

- How do these actors justify continuing their work when presented with empirical research on these schools' mixed impact on the quality of education they provide?

\section{Literature Review on the Emergence of LFPS Globally and in India}

In sum, most literature on the growing prevalence of LFPS provides explanations on a macro scale, and what is missing is the micro-analysis to explain the growth of these schools. Our study fills 
a gap in the privatization and globalization literature as our focus on individuals' motivations to set up LFPS provides this micro-analysis. It is useful, firstly, to review the literature on macro factors contributing to the LFPS expansion. A review of these macro factors allows us to contextualize the environment in which these social entrepreneurs are operating.

Several papers analyze how and why LFPS have emerged and grown across the globe in developing countries from the 2000s. Initially set up on a local scale at the margins of national government, the network of actors involved in LFPS has expanded to a global and political level for several reasons (Walford, 2015). Firstly, James Tooley, an academic and practitioner in the LFPS model, popularized the model and heavily encouraged the expansion of LFPS in its early days. Secondly, international organizations', private foundations' and transnational businesses' support of and funding for LFPS has facilitated its global growth (Verger, Zancajo \& Fontdevila, 2018, p. 24). Thirdly, the increasing globalization of networks further encourages LFPS expansion. International networks enable some of the individual foundations and / or businesses to connect and collaborate (for example at conferences and summits), on deals, further strengthening support of LFPS (Ball, Junemann, \& Santori, 2017). Moreover, the low-fee private school discourse has facilitated a market for these schools. By claiming that LFPS provide a better-quality education than students would receive in state schools, and that they are more affordable than traditional private schools, lowincome and marginalized communities are increasingly sending their children to these types of schools in several sub-Saharan African countries (Verger et al., 2018, p. 24). The establishment of the Millennium Development Goals also enabled the growth of such schools, with supporters touting the ability of these schools in helping developing countries reach their targets at a much lower cost than government school expenditures (Tooley \& Dixon 2003, cited in Ashley et al., 2014).

In India specifically, academics argue that LFPS have expanded for the following reasons: (1) The perceived poor quality of government schools (Chudgar \& Quin, 2012), (2) Parent belief that private schooling provides better quality education (Baird, 2009; Joshi \& Kumar, 2017), (3) Demand for English - LFPS claim to provide English instruction (Baird, 2009; Härmä, 2011), and (4) Regulation mandating that elementary education is a constitutional right for all Indians. This regulation has enabled LFPS to justify their growth by arguing that they are necessary if access to education is expanded to all Indians; the government, it is claimed, does not have the capacity to provide education to all children, so the private sector must step in.

Statistics demonstrate the dramatic growth of LFPS in India: in 2014-15, close to $50 \%$ of all enrolled primary school students in urban areas, and $21 \%$ in rural areas, were attending private schools, whether it was a completely private, private aided or a PPP (private public partnership). Moreover, while the number of private schools increased by 71,360 in 20 Indian states, the total number of government schools only increased by 16, 376 (Kingdon, 2017). More importantly, while private school enrolment increased by 16 million students, government school enrolment actually decreased 11.1 million students.

It is useful to look at the background of the students' parents to better explain why the LFPS phenomena has been so successful. A study of over 50,000 urban and rural households attending private unaided primary schools in 2014 showed that the majority of the parents were self-employed individuals working in agriculture or other sectors. A much smaller fraction of them were regular wage earners. More than 56\% of the households attending unaided private schools said that they chose private schools because they believed that the schools provided a better learning environment. $20 \%$ felt that the government school quality was not satisfactory. Further, $16 \%$ reported that their desire to learn English was fueling their decisions to send their children to unaided private schools (Shankar, 2017).

It is also important to note that despite their prevalence, several studies argue that there is no evidence that LFPS improve student outcomes more so than government schools. Chattopadhay and 
Roy (2017) for example, look at ASER 2016 results to show that government school third grade students demonstrated higher levels of progress than their peers in LFPS. Furthermore, Chudgar and Quin's study (2012) found a poor quality of education in LFPS and critiqued the pedagogy used in such schools. Low-fee private schools are also questioned for their contribution to increasing marginalization. Härmä (2011) studied low-fee private schools in rural areas in a state and found that the fees were screening out students from the lowest-income families. Singh and Bangay (2014) also highlighted economics played a role in the parents' ability to choose between government schools and low-fee private schools.

In conclusion, our review of literature that analyses the reasons for the emergence of low-fee private schools globally and in India demonstrates mostly how large-scale factors contributed to their growth. What is missing, however, is an analysis of the smaller-scale factors, such as the reasons why individuals wanted to set up the schools. By analyzing the motivations of individuals to set up LFPS, our study provides a new perspective on the growth of the phenomena thus enhancing current discussions on the topic.

\section{Theoretical Framework and Purpose}

In this paper we argue that low-fee private school owners are social entrepreneurs, and we will briefly introduce some literature defining social entrepreneurs. We will frame our research study around a social entrepreneurship motivation theory - the push and pull motivational theory - and our literature review will focus on studies using this theory to explain why people set up social enterprises. This theory explains different factors that either push people out of their current jobs/situations to act, or pull them towards taking action because of a deeper internal motivation (formed by various life experiences). This theoretical framework has been used in studies on individuals' motivation to become social entrepreneurs (Humphris, 2017; Yitshaki \& Kropp, 2015) and thus is highly relevant to our study given that we see low-fee private school owners as social entrepreneurs. There have been a number of research studies on social entrepreneurship motivation (Hessels et al., 2008; Humphris, 2017; Yitshaki \& Kropp, 2015), but it appears that very little research has been conducted specifically looking at social entrepreneurs who enter the education sector in developing countries. We intend to find out if the push and pull motivation theory can be applied to our study in order to answer our research questions.

\section{Definition of Social Entrepreneurs}

Whilst there is no single type of social entrepreneur (Certo \& Miller, 2008), many scholars agree that social entrepreneurs both tackle social change intending to create social value (Certo \& Miller, 2008; Dees, 2007; Scheiber, 2015; Weerawardena \& Mort, 2006) and are "financially minded, as social enterprises must be financially sustainable" (Humphris, 2017, p. 3). These characteristics translate to the work LFPS owners are doing, they are financially-minded individuals who tackle social change using a self-sustainable business model. More specifically, LFPS owners can be seen as social constructionists - a type of social entrepreneur (Zahra, Gedajlovic, Neubaum, \& Shulman, 2009). Social constructionists "exploit opportunities and market failures by meeting the needs of neglected clients" (Lönnström, 2015, p. 20). Low-fee private school owners tend to recognize opportunities to address social problems - the failure in education to meet the needs of many lowincome, marginalized families in India.

\section{Review of Literature on the Push and Pull Motivational Theory}

Within the field of entrepreneurship, the push and pull motivational theory has been extremely popular. In this section, we will provide a brief explanation of the push and pull model, 
and then review different studies that have applied this model to explain their findings. Yitshaki and Kropp (2015) studied the push and pull motivation theory to create their model for studying social entrepreneurs, which has influenced the design of our interview questions. Their diagram illustrated below explains this theory:

\section{From Motivation to Opportunity Recognition}

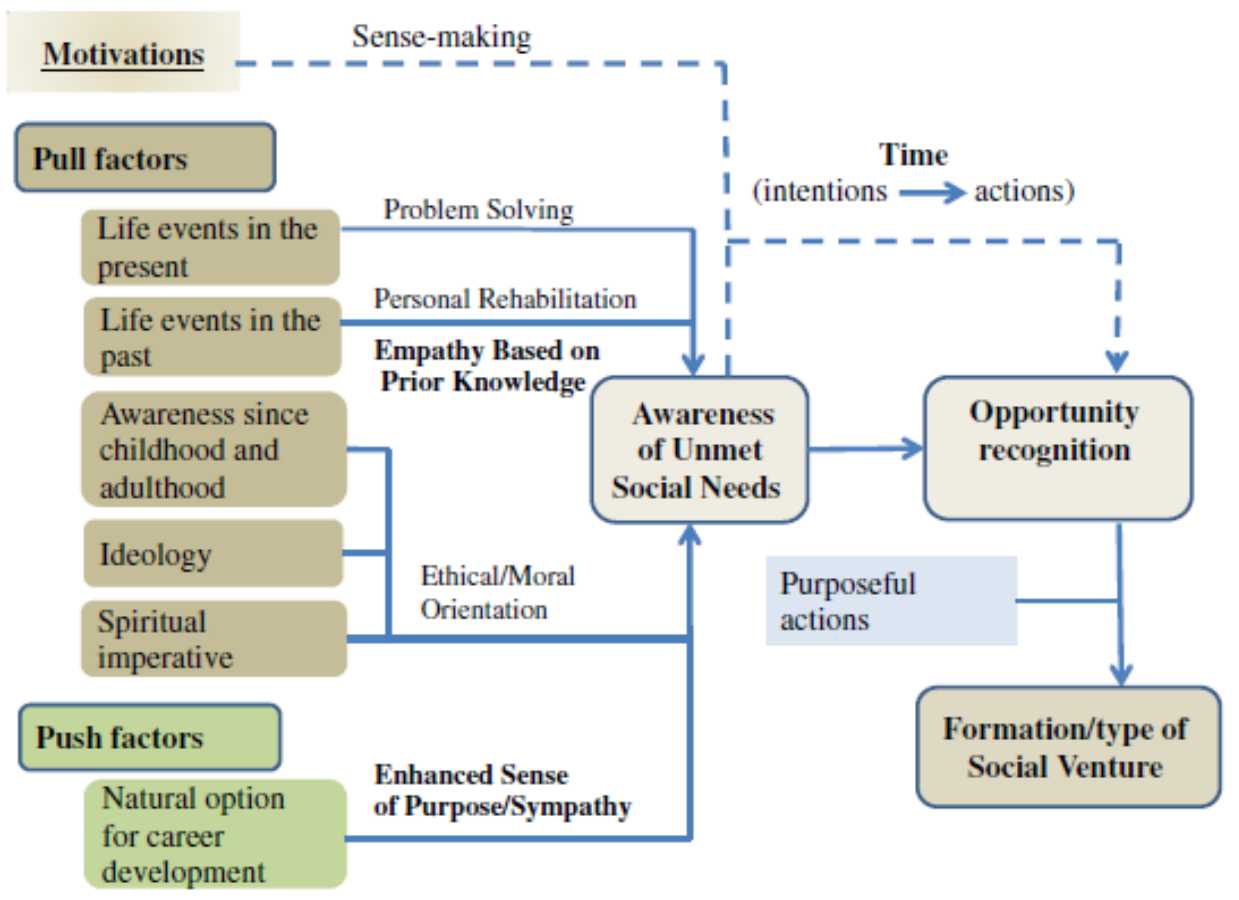

Figure 1: Yitshaki and Kropp (2015) from motivation to opportunity recognition theory

Five specific pull factors lead to an awareness of unmet social needs - the individuals' present and past lifetime events, their ideologies, values and their awareness of a need to contribute to society since childhood. The model looks at pull factors as typically personal and internal to the individual. The individuals' life events and experiences affect both the way they recognize the gaps in society and their ability to convert that gap into an economic activity as well. Ethical and moral concerns are also considered since they may affect the type of business model that they choose to pursue. The model also acknowledges how the social entrepreneurs' existing knowledge contributes to their decision to enter a particular field. Once aware of unmet social needs, social entrepreneurs recognize that there is an opportunity to do something, which in turn leads to forming a social venture. The model, on the other hand, shows that push factors are the ones that ultimately move the individuals out of their previous sources of employment to starting their social ventures. These could include their economic, social or cultural circumstances that influence them to leave their profession.

Yitshaki and Kropp's framework was the basis of a study they conducted on social entrepreneurs' motivations. They used the life story methodology and chronicled the lives of 30 social entrepreneurs in a variety of fields in Israel, such as drug addiction, immigration, and healthcare. They analyzed their data in two stages: 1) Identifying the themes within the individuals' life stories, 2) Categorizing them into push and pull factors. Their study revealed that the pull factors 
(see Figure 1) were the more predominant motivational factors for 18 out of their 30 entrepreneurs. For example, many of the entrepreneurs were influenced to start a social enterprise because of the current problems faced by their family members and their neighborhood. Past life experiences had also instilled certain desires to contribute to society, and these internal desires impacted to their decision to start an organization. Pain, in particular, was a significant motivator from their past. Another key contribution of this study was to identify the roles that prior awareness of particular social issues and prior exposure through family involvement played in motivating the social entrepreneurs.

Hessels et al. (2008) looked at this theory as "necessity vs. opportunity factors" (p. 328). Their study highlights the role played by an entrepreneur's existing circumstances. When social entrepreneurs are driven by pull factors, they tend to have a certain sense of economic and social freedom. On the other hand, the lack of this freedom may amplify the role played by push factors. Hessels et al. (2008) also posit this freedom to be the difference between money as a source of motivation vis-a-vis the desire for independence. Through a multi-regression analysis, their study showed that the country's economic and social situations can determine the primary motive of the entrepreneur. Their study concluded that the tussle between push and pull factors may be determined by the economic factors such as income and the prevalence of social security.

Similarly, Dawson and Henley (2012) argue that many entrepreneurs - within the UK context - may have chosen to be self-employed in social enterprises as a response to their environment, and not because of an internal desire. Their study was conducted during the recession period, and the individuals' environment may have been a factor that 'pushed' them to become selfemployed and set up their own social venture. Because of the recession, the UK entrepreneurs were faced with marginalization as they may not have found employment in the public sector, thus pushing them to seek work into the private sector.

Nguyen (2016) used the life story method to understand the point of entry for social entrepreneurs in Germany. The push and pull theory also allowed the author to delve deeper into the "antecedents of the motivations" (p. 16) and not just the motivation itself. The study revealed that while the pull factors, such as witnessing large scale unemployment among the disabled population or meeting an influential individual, were the initial motivating sources for the 6 entrepreneurs, the point of venture or the "trigger point" was more a result of the entrepreneurs' personal stories and journeys. The study differentiated between an owner's motivations and their "trigger point" or decision to start their social ventures (p. 36). The trigger point may be an accumulation of different experiences that makes them more aware of their opportunities.

Braga, Proneca and Ferreirac (2015) also used qualitative interviews as their method of understanding the motivations of 13 social entrepreneurs in Portugal. Their study aimed to identify if these motivating factors were different for regular and social entrepreneurs, and they found that they were - social entrepreneurs were less motivated by profit. They drew inspiration from multiple theories including push and pull, value expectancy, Vroom's Expectancy, Bandura's self-efficacy and Intrinsic and Extrinsic motivation theories. Their three main findings were: 1) the majority of the motivational factors were pull factors, 2) the majority of the social entrepreneurs were altruistic in nature and 3) they were all influenced by role models.

Humphris (2017) also applied the push and pull theory as a framework for her study of social entrepreneurs in the UK. The author interviewed seven social entrepreneurs, and like Yitshaki and Kropp (2015) she found that the majority of the factors influencing the social entrepreneurs were pull factors. The primary push factor that the study uncovered was the social entrepreneurs' business backgrounds that did not align with their values. In this study, as opposed to other papers, the author 
also uncovered the importance of the awareness of social entrepreneurship models among the participants.

Germak and Robinson (2014) focused on whether personal fulfilment of their visions was a motivating factor for US entrepreneurs in starting their organizations. Their sample covered a total of 1013 entrepreneurs including both traditional and social entrepreneurs. They showed that social entrepreneurs experienced greater self-fulfillment than commercial entrepreneurs, suggesting that self-fulfillment was more of a motivating factor for social entrepreneurs compared to traditional entrepreneurs.

Whilst providing us with an invaluable understanding of the different types of motivational factors that influence social entrepreneurs around the world, two key gaps have emerged from the social entrepreneurship literature review. Firstly, few motivational theory studies have looked at social entrepreneurs in the education sector. Secondly, many of these studies have been based on developed countries and there has not been a focus on developing countries. Furthermore, our study considers the implications of social entrepreneurs' work on marginalized communities and how they can connect these types of communities with the private sector. Our paper, therefore, can contribute to literature on social entrepreneurship motivation theories by including what is currently missing the education sector (low-fee private schools) in a developing country (India), and by explaining how social entrepreneurs can act as a bridge between marginalized communities and the private sector. What's more, by incorporating social entrepreneurship motivation theories, our paper also intends to fill a gap in literature on low-fee private schools; while studies on LFPS have focussed on the impact on student learning and the equitable distribution of school systems, very few have studied the individuals behind the phenomenon. Additionally, our analysis of the impact of individuals' motivations to set up LFPS on marginalized communities adds a new perspective to the study of social entrepreneurship.

To conclude, reviewing literature on both social entrepreneurship and the macro-analysis of the growth of LFPS, our study aims to bring together and contribute towards several strands of scholarship- low fee private schools, social entrepreneurship, education privatization, globalization and marginalization.

\section{Research Design and Methods}

\section{Research Design and Participants}

This study adopts qualitative research methods, using interviews as a research tool. Our interview questions aim to answer both our research questions; firstly, what has motivated the individuals to start a low-fee private school and how they justify continuing to work in the sector despite the mixed evidence of the impacts of LFPS. Appendix 1 shows our questions, which draw on a number of themes within the push and pull framework, such as life events, trigger moments, an awareness of the sector before entering it and ideological beliefs (Yitshaki and Kropp, 2015).

Our research participants are individuals who have set up at least two low-fee private schools in India. Given the increasing scrutiny over LFPS chains as opposed to individual schools, we chose to focus on individuals who aspired to expand their model to communities outside of their own. While not a sampling criterion, our participants are all Indian, and have set up schools in the urban cities of Pune, Bangalore and Hyderabad from different states. All three cities have experienced an increase in the number of LFPS compared to other cities in the country (Jain, 2012). These cities are also representative of the typical target market for LFPS - a growing working class where parents are willing to invest in their children's education. We interviewed eight people after getting IRB approval. 
Table 1

Description of participants

\begin{tabular}{lllll}
\hline $\begin{array}{l}\text { School } \\
\text { Owner }\end{array}$ & Prior job & No. of schools & $\begin{array}{l}\text { No. of } \\
\text { students }\end{array}$ & School fees \\
\hline B & Student & 2 & 1300 & $\begin{array}{l}\text { INR } \\
8700 / \text { year }\end{array}$ \\
E & Business (Garments) & 4 & 3000 & $\begin{array}{l}\text { INR 16,000/ } \\
\text { year }\end{array}$ \\
F & Tutor and lecturer & Unsure (at least 2) & 2000 & INR \\
& & & & $6,000 /$ year \\
D & $\begin{array}{l}\text { Psychology student (Mother } \\
\text { started the school) }\end{array}$ & 2 (one more being & 600 & INR 10,000- \\
& Bank employee & At least 2 & 27,000
\end{tabular}

$1 \mathrm{INR}=0.014 \mathrm{USD}$

\section{Data Collection Methods and Analysis}

Our data was collected through convenience sampling and snowballing. We took advantage of social networks, and reached out to our contacts in India, and then asked them if they could put us in touch with people they knew who had set up at least two low-fee private schools.

We conducted our interviews via phone or Skype, and the interviews were recorded. Once transcribed, we parsed and coded them using the emic and etic (open and closed) method to identify key themes. We then created a table summarizing the main themes from the push and pull framework and how many interviewees mentioned one of these themes (Appendix 2). We analyzed the responses by organizing their motivations according to the ones listed by the Yitshaki and Kropp (2015) framework. The theory, therefore, laid the foundation of the kind of motivations that we were looking for through the interviewees' responses. We also analyzed the interview responses to identify any other themes not covered by the theory.

\section{Methodological Limitations}

We recognize a number of limitations in our study. Firstly, given our small sample size we cannot generalize all owners' motivations for setting up LFPS nationally and internationally. Secondly, the lack of Hindi from one of the researchers meant that the interviews were conducted in English, English was not the first language of any of the school owners, and for some of them we had a harder time getting very coherent and clear responses. We, however, attempted to overcome 
this limitation by encouraging the owners to speak in Hindi/a language of their choice when they were more comfortable in that. Thirdly, our access to the owners was through our personal and professional contacts. These owners had some level of existing support to professional development already and this may represent a selection bias in the kind of owners who were willing to participate in the study. Further, we used Yitshaki and Kropp's framework (2015) because of their popularity with the social entrepreneurship motivation theories but not their chosen method, the life story. We instead adopted qualitative interviews for this purpose. The lack of time and the lack of physical proximity to the owners prevented us from fully utilizing the life-story method, which could have provided richer findings.

\section{Findings}

The findings have been presented in two sections. Our first section addresses the motivations for these individual actors in setting up the low-fee private schools. The second section focusses on how these actors justify their continued presence despite the lack of robust evidence of their impact.

\section{What are the Motivations of Individual Actors in Setting Up Low Fee Private Schools?}

Through our interviews we identified several sequential processes in leading to the decision to set up a low-fee private school: 1) A motivation to set up a social venture in education, 2) Factors leading to entering the private education sector/non-donor-based sector, and 3) Factors leading to working in the low-fee model. Our findings section will therefore be arranged in three sub-sections, each representing one of these particular processes of decision-making.

Setting up a social venture in education. All of our school owners experienced social awareness since childhood or early adulthood (from the $\mathbf{Y} \& \mathbf{K}$ framework), which in turn inspired them in varying capacities to enter the education field as a form of social venture. They all had a family member who either worked in or spoke about the importance of education to improve life outcomes. Owner E said that it was his father's dream for him to work in education, owner B found inspiration in her mother-in-law who was a teacher and who ran her own school. Moreover, owner D's mother and owner H's brother had started the schools that they would go on to own. Owner D also spoke about her awareness since childhood of the importance of giving back to society. She said that her grandfather was a freedom fighter, and used to say "when we are born as a human being, we need to repay our debt to land, people and nature". Owner A's mother had wanted her to become a teacher and explained the advantages of a secure teaching career for family work-life balance, and owner G's wife worked in a low-fee private school. Finally, owner F's father had encouraged him to set up a school, explaining that he would have a more sustainable impact on students' education if he had his own school as opposed to tutoring individual students.

Six owners were motivated to set up a LFPS as a means of resolving unmet social needs based on a present problem (Y\&K framework). Owner B explained that her husband, who had the idea to set up a school, was surprised when he saw so many children working in the center of the city and not going to school. This triggered him to want to act and ensure that children were educated. She said "many kids are working in the shops. Schools are surrounded by clothes, vegetable, slaughterhouse, flower markets - attracting child labor. As he was from the same community and society, born and brought up in the same area, he was not able to understand what's stopping them from schooling”. Owner C spoke about his awareness of the poor quality of education in India, but pointed to one moment that made him particularly attuned to the problem of quality education. He said 
...I remember the penny dropped for me when I was conducting this class [at university] and I had given a case study to my students, and when they came...they hadn't really thought it through. I was wondering why in a class of 60 there was no one who could really critically think, and I realized that the problem goes far back, it's far deeper from what I could resolve in that class. It went back to their schooling, the science, foundations in thinking, communication, and I realized that what I'm trying to do is not possible in graduate courses, I've got to go back to school education.

Furthermore, another owner (A) explained that she witnessed the difficulties low-income families faced when trying to get a good education when she was working in a bank in the loans department. This job position meant that she was frequently giving loans to very low-income families for education. Identifying this problem as well as recognizing the lack of schools in close proximity to the urban area in which she was working / living motivated her to set up a school. Similarly, owner G spoke of the lack of schools in his area, he said that there was "no school in vicinity of five KM" and that there was a "bridge to cross" making it hard for children to access schools. This problem, alongside other factors, encouraged him to set up a school. Tackling unequal access to marginalized communities, therefore, served as a strong motivating factor. Another owner (E) expressed the present problem manifesting through people's inability to fill in official forms / documents at the bank. He said that when he was a businessman and went to the bank, he found that even people with money "could not fill a challan [form], in a proper way" and that "students were struggling a lot, parents from our area couldn't pay fees". The owner also identified a problem with the lack of education in his area after speaking to parents who generally preferred that their children worked rather than go to school. Facing high levels of poverty and unstable incomes forces families from these communities to rely on multiple income sources, forcing students to choose between education and work. Witnessing both people's difficulties at the bank alongside the parent's desire for their children to earn money inspired him to help resolve the problem of the low levels of education at lower fee levels. Finally, owner $\mathrm{H}$ identified an issue with the school that his brother was managing. He found that the school lacked proper systems and that the teachers were more concerned about themselves and not the students who were struggling.

Entering the private / non-donor-based education sector. There were four key findings that explain why the owners entered the private education sector as opposed to the government sector and / free / donor-based schools: 1) Distrust in the government education system; 2) The perception that parents do not value free education; 3) They believed it was the only way to provide a sustainable education for students; and 4) The private sector allowed for greater flexibility in terms of both curriculum and professional development.

Distrust in government education system to provide a good quality education. There was consensus amongst all but one owner concerning this point. When asked why they chose not to work in government schools, the owners felt that systemic issues in the government education system prevented good quality education, which in turn may have impeded them from positively impacting students. For example, they spoke about the amount of administrative work that prevents teachers from focusing on their teaching (owner A), the lack of motivation on the teachers' part because of low salaries and low accountability (owner G), and practices of corruption. Owner F said that the "Indian government runs with bribed persons. They earn high salary whether they do it [the job] or not. I don't like the government way of doing things." and owner A expressed concerns over the lack of quality, explaining that "the teachers [in government schools] are busy doing administration work or other work. The children are not getting an education." The owners' idea of 
good quality education has several characteristics. The first is good teachers (owner E). Though they do not specify what traits a good teacher has, we can infer that motivation is a trait they are looking for as they mention the lack of motivations government school teachers have especially in terms of them not going to school regularly. A second characteristic is connecting schooling to everyday life (owners $\mathrm{C}$ and $\mathrm{H}$ ). A third characteristic is measures of learning outcomes - some owners mention the better results in LFPS as compared to government schools (owner $\mathrm{G}$ and $\mathrm{F}-$ The results of the SSC and PUC [national exams] is better with private schools - C, B), and owner B mentioned that Educational World Research had ranked her school in the top 14 budget private schools in India. The most recent ASER results however, are evidence that government schools', at least in rural areas, exam results are rising (ASER, 2018). These results may challenge the claim that private schools always have better exam results that government schools. A fourth characteristic is literacy owner A said "children should be good in speaking, reading and writing in all three languages" and owner $\mathrm{H}$ agreed with this and felt that listening was important as well. A fifth characteristic is educating children to be good, moral citizens - owner C says quality education is "something that prepares a student to become a capable adult, a responsible citizen and a good human being", owner E said that education should "build leaders to build the nation", and owner F said "I want children to be loyal citizens to the country. I want to teach them humanity, peace and prosperity." The last characteristic of good quality was strengthening students' social and emotional development (owner $\mathrm{H})$.

The perception that the parents do not value free education. Another reason that led to the owners' decision to set up a fee-paying school as opposed to a free one is their perception that parents do not value free education. They felt that the parents would be more invested in their children's education if they paid something, even if it is a small amount. Owner B believed that "when you get something free you generally don't value it" and owner E explained that "if they pay something, they will feel like they have some value, they will feel like they sacrificed for school". Moreover, owner A stated "If the parents pay fees, they take it [school] seriously", this idea is supported by owner D, who said 'if this [school] was free, people become complacent", and by owner G, who says "parents' notion is that the free [school] means no quality; free [means that you] cannot question management." Finally, owner $\mathrm{C}$ also implies that parents do not value free education, saying that the "most sustainable models are where parents see value and are paying for it".

They believed it was the only way to provide a sustainable education for students. Only one owner $(\mathrm{C})$ explicitly said that a fee model was essential to ensure a school is sustainable. He said that he "didn't want the school to be dependent on the whims of donors, which may change. With parents paying they are showing a commitment, thus making the schools sustainable." However, while others did not explicitly mention sustainability, they highlighted their inability to obtain funds to set up a free school, implying this belief. Five of the owners explained that they could not afford to set up a school that was free. Owner A discusses the need to have a sustainable workforce, saying that "totally free [is] not done because I had to pay teachers - need to get good teachers...to give teachers and pay them, we need... money." Owner B expresses concerns with how they can set up a school, saying "we don't get funds from anywhere". Owner H said

Free school doesn't work, it works only to a certain level, a mini level. If we have to run in a micro level, we have to collect fees. If we have a dedicated team of people who really want to work for society. .... Because we need to spend money on teachers, qualified teachers with good skill and education. $70 \%$ of expenses goes on 
teacher salaries. Out of the remaining expenses, most goes to rent. Then we have electricity, telephone, misc. expenses and all.

The private sector allowed for greater flexibility. Two of the owners spoke about the greater flexibility in the private sector regarding both professional development and curricula design. One pointed out that "in the private sector, we can make decisions". This owner spoke about the ability to change the school schedule in the private sector, explaining that in her school, "We can think about the children and make changes accordingly" such as changing when exams happen so that they do not fall just before Diwali. Another owner (F) spoke about the room for professional development in the private sector, which does not appear to exist in government schools. He said: "government schools don't have any room for expansion" and he highlights that in the private sector he has been able to grow and change his job, saying, "I was a teacher, then a lecturer and today I am a principal and secretary". Within the government system it is difficult for the owners to choose which teachers they hire and how to develop the curriculum. Although certain current government regulations such as minimum teacher qualifications and infrastructure apply to low-fee private schools, other academic and administrative freedoms allow the owners a greater degree of flexibility. Therefore, they believed that they would have a better chance of making a difference in the private sector where there had more freedom to hire and train the teachers they wanted, and to create a school with their vision of what quality education should look like.

Working in the low-fee education model. Another key finding that our interviews unearthed was the importance of setting up a private school affordable for their community. The majority of the owners realized and understood their target market and clientele - low-income families, and they realized that elite private schooling was not accessible to the population that they were looking to serve. There are, however, no standardized definitions of affordability and lowincome. Owner A said, "If we start a high-income school, we need high-infrastructure, but we could charge only low-fees anyway". Second, two owners also felt that education needed to be affordable. "This is not a business", was mentioned by several owners. According to owner B, "our vision is to keep as low free structure as possible so that each and every child get the education they deserve". Another owner (D) also spoke about how she felt that schools need to be run where the fee collected is distributed and used for teacher salaries and educational purposes without any commercial motives.

\section{How Do These Actors Justify Continuing Their Work Despite the Lack of Robust Evidence on Their Positive Impact?}

Firstly, it seemed that most owners were not aware of the research highlighting the questionable impact of low-fee private schools. All the school owners felt that LFPS were providing better quality education than government schools. They had such negative attitudes towards government schools that they tended not to believe the lack of robust evidence on their positive impact once we told them about it. Despite the evidence of LFPS' mixed results, LFPS were still said to be better than government schools as they provide more flexibility in terms of the curriculum and the teaching style (owner A), and because LFPS teachers are more dedicated to their students (owner G). The owners also pointed to evidence of decreasing government school enrolment and government school closures to provide their point (Kingdon, 2017). Owner F said

If it [the poor impact of LFPS) is so why do parents continue to go to private schools? If they are paying, why will parents not choose free education? The results of SSC and PUC [national exams] is better with private schools.... there are government schools closing down... They are putting a lot of efforts to improve the quality 
education [in LFPS]... Compared to government schools, they are better. I don't know what research you are talking about.

Another reaction to the lack of robust evidence on the positive impact of LFPS was that LFPS cannot be generalized, there are many differences amongst them, and that the evidence did not apply to their schools - they claim that their schools did in fact have a positive impact on student outcomes. Owner B spoke primarily about the greater opportunities for students in her schools than in government schools. For example, she mentioned organizations who come into her schools to provide sessions and workshops on soft skills. Owner D was aware of the challenges of low-fee private schools, but said that "as far my school is concerned - 100\% SSLC results". Owner B spoke about seeing girls from that community go to college for the first time because of her school. Owner $\mathrm{H}$ emphasized that he did have evidence that LFPS can lead to positive learning outcomes, speaking specifically about the progress of his students' handwriting and speaking skills. Finally, owner C articulated the lack of validity in generalizing all low-fee private schools into the same bucket with the following explanation:

What we have learnt in India is that with anything less than US $\$ 150 /$ annum fees, it is impossible to deliver good education, economics does not work out. By the time you have paid for material and rental, you have very little to pay teachers. You cram 50-60 kids in a class, have poor talent and there is no hope in hell for good education. Only if you go above $\$ 200$ level, you start to get flexibility in the right places, do you at least have the ability to deliver good education. Once you have the structure in the fees, you can invest in the right curriculum, pedagogy, teacher capability.... If we measure at the lower end, of course we will get poorer outcomes. There are more in the spectrum where we see better learning.

\section{Analysis and Discussion}

The push and pull theory has helped us to understand and characterize the motivations of individuals to start a social venture within the education field. Our first two point of analysis will discuss 1) the higher number of pull than push factors, and) how interviewees' motivations are grounded in pull factors rather than a specific trigger moment. We will then continue to discuss: 3 ) The difficulty owners had in defining 'quality' yet their frequent usage of it 4) How the findings exemplify the gap between ethical and moral concerns within academic research and the lack of these concerns when confronted with immediate needs on the ground, and 5) How the findings suggest that owners did not seek the LFPS model, but that their decision to enter it arose from a lack of motivation to enter the government sector and as a response to types of communities (low-income communities) in their areas. Lastly, we will discuss more explicitly 6) how our findings connect to the marginalization, privatization and globalization.

\section{More Pull Than Push Factors}

Our coding method highlighted several pull factors from Yitshaki and Kropp's framework in particular that led to setting up low-fee private schools. The two most popular factors were i) present life events: identifying a problem and ii) awareness since childhood of a need to contribute to society: Family member. Only one interviewee discussed dissatisfaction in her current role as a factor pushing her to set up a LFPS, and one other spoke about his desire to seek more meaning in his life

${ }^{1}$ The SSLC is the standardized class 10 leaving examination that students across the country take. 
as pushing him towards setting up a LFPS. These findings align with several research papers that have been discussed in our literature review. For example, Braga, Proneca and Ferreirac (2015), Humphris (2017) and Nguyen (2016) all revealed that pull factors were more influential than push factors in their studies. The fact that there were more factors pulling the owners towards setting up a low-fee private school than factors pushing them out of their current situation highlights their active choice to do something for their community. Interestingly, none of the owners spoke about the desire to make profit as a pull factor, but the factors were shaped by a desire to help their community. We therefore cannot infer that profit was or was not a pull factor based on our interviews. Contrary to assumed motivations, privatizing education did not arise from a desire to make profit, but a desire to give back to their community and believing that the private sector was more effective than the public sector at providing quality education.

\section{Motivations Are Grounded in Pull Factors Rather Than a Specific Trigger Moment}

From our findings, it seems that individuals' decisions are strongly influenced by people around them, and it highlights the formative nature of childhood. Furthermore, our findings are similar to Yitshaki and Kropp's findings (2015). They recognized that the "social entrepreneurs' discovery of new opportunities is based on unique life experiences and prior knowledge that creates a "knowledge corridor" [a knowledge base that is drawn upon to make decisions] and an ability to recognize opportunities that others might miss (Shane 2000).” (Yitshaki and Kropp, p. 12). The idiosyncratic life experiences of our interviewees, whether it was studying and working abroad (owner C), working in a bank (owner A), or starting a business (owner E) for example, combined with prior awareness of the importance of social responsibility helped create the "knowledge corridor", which in turn allowed them to understand how they could help improve quality education in their community. The "knowledge corridor" was likely strengthened by many factors. For example, social networks likely led to hearing anecdotes on the poor quality of government schools. Similarly, as Nguyen (2016) showed with his study in Germany, whether these pull factors serve as exact trigger points is debatable. Out of six pull factors, half of them were found to be associated with triggers. Similarly, in our study, while six out of eight owners spoke about how a particular incident influenced them, it was not an isolated incident alone for the majority of the owners. Our study also showed similar results to Braga, Proneca and Ferreirac (2015), particularly with respect to the importance of role models. Contrasting with the study by Dawson and Henley (2012), our study did not unearth any evidence of push factors or the ease of the legal environment.

It is also important, however, to note that Hessels, Van Gelderen and Thurik (2008) highlighted that the economic and social circumstances of the social entrepreneurs can alter the influence of the push factors. Most of the owners in our study were well-settled in their alternative careers and did not speak about any financial difficulties while starting their social ventures. This could explain why there were more pull than push factors in their motivations and their journeys.

\section{Government Schools Believed to be Low Quality by Owners}

The owners perceived notion of the quality of government schools was a strong influencer in entering the private sector. Our interviews showed that the owners developed a negative perception of the government schools' value and worth based on their interactions with parents, students, acquaintances, and their own personal experiences of having difficulty in meeting government regulations. It is likely that their belief in the poor quality of government schools is influenced not only by their immediate surroundings but by the media and the national rhetoric on the poor quality of the Indian education system. They also spoke about the government schools as a group. They appeared unable to speak about any positive experiences with government schools, mimicking the language used by proponents of charter schools and voucher programs. Scholars such as Pizmony- 
Levy and Torney-Purta (2018) have spoken about the power of rhetoric regarding government schools in influencing people's opinions of them, particularly with respect to results of ILSAs. ILSAs have contributed to further globalization of education, and the rhetoric of the inadequacy of government schools is a global phenomenon. Our study shows the power of the rhetoric surrounding the poor quality of government schools in influencing individuals to set up private schools, despite a lack of evidence that government schools are failing across the board.

\section{Prioritization of Immediate Needs on The Ground}

Whilst there is strong academic evidence to suggest that the expansion of low-fee private schools may have adverse effects on equity in terms of access and outcomes in India (Härmä, 2011; Singh \& Bangay, 2014; Tilak, 2016), our conversations with the owners suggest that they did not have any such concerns in their mind. The owners' concerns were more tied with the local communities' needs vis-à-vis the country. They, in fact, felt concerned about the potential absence of such opportunities for their students in light of their perceptions of the government schools. This concern, therefore, suggests a gap between moral issues raised within academia (growing marginalization of communities who cannot access LFPS, and concerns surrounding the right to access free education) and the situation on the ground (the absence of a government school in a community). Further, the owners' micro perspectives may be influenced by their professional background. The majority of the owners tended to come from a business rather than an academic background, and so had not been in an environment that encouraged them to critically reflect on the macro implications of different models of schooling. It may not be a priority for them to see the larger ill-effects of low-fee private school expansion; they saw an opportunity and prioritized helping their community above anything else. As Owner (C) said, "the ethical argument is mute here". It seems that the schools were set up to support a particular marginalized community, but other marginalized communities further away likely are unable to access these schools. As a result, the LFPS model may polarize marginalized communities, whereby some communities have access to schools and other communities who remain without access are further pushed to the margins of society.

\section{The LFPS Model Arose from Environmental Factors}

The specific 'opportunity recognition' to set up a low-fee private school can be mapped, to an extent, using the Yitshaki and Kropp framework: present and past life events and an awareness since childhood/adulthood of the poor education that many Indians receive led the owners to recognize an opportunity to set up a school. Nonetheless, there were more context-specific factors that contributed to their belief that this particular model would be the most effective. The owners were motivated to work in the private sector as they strongly believed that they could not have a strong positive impact on students' education in the government schools. Further, one owner $(\mathrm{H})$ also did not realize that it was even an option to work in government schools. Owners wanted to create a sustainable school where everyone values the type of education provided in that school. Their decision to set up a low-fee school stems from the characteristics of their communities, and at times the lack of a school accessible to their community. In other words, their decision arose from the marginalization of their communities. Our first two findings tell us that the communities the owners served were from a low-income background. If the owners wanted to educate their communities outside of the government system, it appears that there was little choice but to set up a low budget school, as the families would not be able to afford to pay high school fees. Nonetheless, it is important to note that one of our owners (owner C) did say he was not motivated to work for the privileged group children. 


\section{Further Connections to Marginalization, Privatization and Globalisation}

It is clear that the low-fee private school sector both contributes to and is a result of marginalization, privatization and globalization. The increasing globalization has led to the growth of the informal economy in many developing countries, particularly in India (Banergee and De, 2018). The informal economy consists of businesses that are not regulated by the government, and this environment provides an expanding opportunity for low-fee private school owners. The growing labor class with a desire for good quality education serves as the ideal population for low-fee private schools, and these schools can be set up easily given the lack of regulation, red tape and accountability imposed on them.

In terms of marginalization, existing studies claim that LFPS contributes to the increasing inequity in terms of race and class (Härmä, 2011; Riep, 2017). This study showed that marginalization alone can be a direct motivator for the owners. Economic marginalization faced by families leading to disproportionate income distributions across the country is an important factor to consider here. The majority of the owners we interviewed specifically spoke about the trigger they faced when they saw marginalized communities and hence decided to start their schools. However, as highlighted before, the owners also did not consciously see their role in possibly perpetuating this marginalization since their fee model essentially keeps a section of students out of their schools. The school fees, therefore, are often not static, thereby leading to further marginalization of subgroups because of the consistently rising school fees. Another group of individuals who are faced with a difficult choice are the teachers. Almost all the owners acknowledged the role played by the teachers in rising the school quality and the need for professional development for them. However, as much as the private sector provides the owners with the flexibility that they need, it should be kept in mind that the room for professional development is dependent on their ability to raise funds either through donors or increased school fees. This, however, can also work against teachers since the low-costs come at the cost of teacher salaries (Chattopadhay \& Roy, 2017).

It is clear that the owners were also choosing this model of schooling because of their perception that the parents will be more invested in their child's schooling only in a fee paid model. The majority of the owners also strongly believed the private sector model will lead to increasing accountability to the parents and the community. Increasing accountability to parents and communities is one of the most common justifications used to explain the growth of low-fee private schools. According to Kingdon (2017), salaries of Indian government teachers were seven times as much as certain states' per capita income, and this is higher than the case in other developing Asian countries such as China and Bangladesh. Proponents of low-fee private schools claim that low-fee private school teachers are able to deliver better test results at much smaller salary figures and hence, are able to provide better accountability to marginalization communities, very much reflecting a neoliberal narrative. This narrative has led to the growing privatization of education, and the owners in our study are proponents of this narrative, explaining that they do not see value in working with the government to solve these social issues and would rather use a fee-based model because that is where they see their ability to create impact. Having said that, the study also did not uncover profit as a key reason to choose to start LFPS and this is counterintuitive to the typical individual motives in the private sector. This could also suggest that there may be a certain type of owner who may be more tuned to the needs for the LFPS sector.

\section{Conclusion}

Our findings suggest that there are benefits to the low-fee private school - they provide an education to children who would not have gone to school due to a multitude of factors (such as a 
lack of schools in close proximity to their home and / or parents distrusting the government schools). As a result, giving a voice to the individuals who have set up the schools may lessen the demonization of these schools, as it allows critics of low-fee private schools to understand the intent of the individuals who set them up. The school owners who we interviewed were motivated to provide a quality education to the marginalized communities they serve, and they believe that private education was the only option to provide this quality education.

Nonetheless, given the magnitude of criticism towards low-fee private schools, our findings also have policy implications for promoting alternatives to the LFPS model. A wealth of literature indicates that low-fee private schools are not helping the most marginalized communities and also that they are infringing upon the right to education for all children (Härmä, 2011; Lubienski, 2013; Riep, 2017; Singh \& Bangay, 2014; Tilak, 2016; Torche, 2005). Further, the growth of these types of schools can remove government accountability to educate the most disadvantaged groups across the world. If we want to shift gears in how to improve both education quality and access for all and ensure that governments fulfil their responsibility to educate all citizens, we need to focus our attention on the people setting up the low-fee private schools, and the conditions to which they respond. Our study shows that there are individuals with means who wish to contribute to society, and therefore greater attention towards policies and / or practices, which could influence some of the more financially privileged people in Indian society who have a desire to give back to the community, may be beneficial. Our findings highlight that there are people who have limited knowledge of the sector and do not know alternative ways to help improve the quality of education. Therefore, we propose the introduction of policies that increase awareness of ways to support education. For example, increasing advertising for programs that train government schools' principals and teachers, and for existing educational non-profits in the media can make individuals aware of opportunities in the education sector. As a result, individuals may choose a different pathway to work in education as opposed to setting up a low-fee private school.

Secondly, our study calls for a change in the current policy discourse of government schools. Our findings have shown that the owners may find the low-fee private school model as the most suitable model for them primarily because of their massive distrust of the public schooling system in India. While their perception of government schools is in part influenced through their discussions with their own personal networks such as prospective parents, other owners, and teachers, and experiences with government officials, it may also come from the global media discourse surrounding the failure of the public education system. For example, the media, which reports on India's performance in international large-scale assessments (PISA 2009) and national assessments (ASER) where the country has ranked relatively low in mathematics, English, and science results (ASER 2018; Saha, 2017), contributes to the aforementioned negative discourse. The growing globalization of assessments and education models provides further justification to introduce and expand models of education perceived to improve the quality of learning. This discourse facilitates the private sector entering the education system, which justifies its presence by building on the negative discourse surrounding state education and arguing that it is needed to improve education. The motivations of LFPS owners to improve the quality of education therefore reflects the global discourse that justifies privatization in education (that it is necessary to improve the quality of education because of the failure of the public education system). Our paper thus demonstrates the power of a global discourse - even when that discourse is not based on empirical evidence showing that it can enable concrete changes to happen on the ground. A change in narrative about the possibility of transformation in government schools may persuade such individuals to focus on changing the existing government system.

Low-fee private schools educate some of the poorest communities across the globe, and going forward, more needs to be done to truly to get a more holistic understanding of how they 
function in order to ensure that impoverished communities in many countries are accessing the best quality education possible. Firstly, further studies could see if our findings resonate with individuals' motivations to set up LFPS in different countries. Secondly, studies focusing on the motivations of LFPS donors could help explain the growing phenomena, because funding contributes to the growth of these schools. We have a significant way to go before the world leaders successfully address the inequities in terms of both access and quality in education. Learning more about individuals' motivations to start LFPS is a step towards better understanding their growing prevalence. This understanding of why and how the schools are managed can both help policy makers ensure that the schools are run in the most equitable way possible and can provide incentives to improve the quality of government schools so that access to education is free for all children, thus reaching the goal of Education for All.

\section{Acknowledgements}

We were both inspired to research this topic after attending a privatization-related class at Teachers College. We would like to thank Professor Camila Addey and our classmates for influencing us and pushing us to think deeper. Thank you to Professor Samuel Abrams and Professor Camila Addey for their guidance in helping us further refine our research questions. We are very grateful to our research participants for sharing their life journeys with us.

\section{References}

ASER. (2018). Annual status of education report (rural). New Delhi: ASER Centre. Retrieved from http://img.asercentre.org/docs/ASER\%202018/Release\%20Material/aserreport2018.pdf

Ashley, L. D., Mcloughlin, C., Aslam, M., Engel, J., Wales, J., Rawal, S., \& Rose, P. (2014). The role and impact of private schools in developing countries: A rigorous review of the evidence. Final Report. London: DfID

Baird, R. (2009). Private schools for the poor: Development, provision, and choice in India. Chennai: Grey Matters Capital. Retrieved from http:/ / dise.in/Downloads/Use\%20of\%20Dise\%20Data/Ross\%20Baird.pdf

Banerjee, S. \& De, N. (2018). India's informal employment in the era of globalization: Trend and challenges. IOSR Journal of Business and Management, 20(4), 12-20. Retrieved from http:/ /www.iosrjournals.org/iosr-jbm/papers/Vol20-issue4/Version-3/C2004031220.pdf

Ball, S. J., Junemann, C. \& Santori, D. (2017). Edu.net: Globalisation and education policy mobility. Taylor and Francis. https://doi.org/10.4324/9781315630717

Braga, J. C., Procença, T., \& Ferreira, M. R. (2015). Motivations for social entrepreneurship Evidences from Portugal, TÉKHNE - Review of Applied Management Studies, 12(1), 11-21, Retrieved from: LUSEM Library website http://www.lusem.lu.se/library https://doi.org/10.1016/j.tekhne.2015.01.002

Chattopadhay, T., \& Roy, M. (2017). Low-fee private schools in India: Emerging fault lines. Working Paper 233. Center for the Study of Privatization in Education, Teachers College, Columbia University, Retrieved from http://ncspe.tc.columbia.edu/center-news/working-paper-lowfee-private-schools-in-india/

Chudgar, A., \& Quin, E. (2012) Relationship between private schooling and achievement: Results from rural and urban India. Economics of Education Review, 31(4), 376-390.Retrieved from https://doi.org/10.1016/j.econedurev.2011.12.003 
Certo, S. T., \& Miller, T. (2008). Social entrepreneurship: Key issues and concepts. Business Horizons, 51(4), 267-271. https://doi.org/10.1016/j.bushor.2008.02.009

Dawson, C., \& Henley, A. (2012). Push vs. Pull entrepreneurship: An ambiguous distinction? International Journal of Entrepreneurial Behavior and Research, 18(6), 697-719. https:/ / doi.org/10.1108/13552551211268139

Dees, G. (2007). Taking social entrepreneurship seriously. Transaction Social Science and Modern Society, 44(3), 24-31. https://doi.org/10.1007/BF02819936

Germak, A. J., \& Robinson, J.A. (2014). Exploring the motivation of nascent social entrepreneurs. Journal of Social Entrepreneurship, 5(1), 5-21. https:/ / doi.org/10.1080/19420676.2013.820781

Härmä, J. (2011). Low cost private schooling in India: Is it pro poor and equitable. International Journal of Educational Development, 31(4), 350-356. Retrieved from https://doi.org/10.1016/j.econedurev.2011.12.003

Hessels, J., van Gelderen, M., \& Thurik, R. (2008), Entrepreneurial aspirations, motivations, and their drivers. Small Business Economics, 31(3), 323-339. https://doi.org/10.1007/s11187-008-9134-x

Humphris, G. (2017). Motivations of social entrepreneurs. University of Huddersfield. Retrieved from http:/ / eprints.hud.ac.uk/id/eprint/31346/1/2017_Humphris_BUS.pdf

Jain, R. (2012). Affordable private schools: Sector Analysis Report-2012. Bengaluru: Gray Matters Capital. Retrieved from http://centralsquarefoundation.org/wpcontent/uploads/2016/02/Affordable-Private-Schools-Sector-Analysis-Report.pdf

Kingdon, G. (2017). The private schooling phenomenon in India: A review. IZA Institute of Labour.

Lönnström, A (2015). The Motivational Values of Social Entrepreneurs. (Doctoral dissertation). Retrieved from https://jyx.jyu.fi/bitstream/handle/123456789/46261/URN:NBN:fi:jyu201506102258.pdf?sequence $=1$

Lubienski, C. (2013). Privatizing form or function? Equity, outcomes and influence in American charter schools. Oxford Review of Education, 39(4), 498-513.DOI:

10.1080/03054985.2013.821853 https://doi.org/10.1080/03054985.2013.821853

Nguyen, D. (2016) Social entrepreneurial motivation: An exploration of the antecedents based on the life story method. (Master's thesis). Retrieved from https://lup.lub.lu.se/studentpapers/search/publication/8896159

Pizmony-Levy, O., \& Torney-Purta, J. (2018). How journalists and researchers communicate results of international large-scale assessments. CADMO, 1, 51-65.

https://doi.org/10.3280/CAD2018-001007

Riep, C. (2017). Making markets for low-cost schooling: The devices and investments behind Bridge International Academies. Globalisation, Societies and Education, 15(3), 352-366.

Saha, D. (2017, April 17). In 5 years, private schools gain 17 million students, government schools lose 13 million. Hindustan Times. Retrieved from https://www.hindustantimes.com/education/in-5-years-private-schools-gain-17-millionstudents-government-schools-lose-13-million/story6FV1ic7RLttmWc0ZkhBQBM.htmlScheiber, L. (2015). How social entrepreneurs in the third sector learn from life experiences. Voluntas, 27(4), 1694-1717. https://doi.org/10.1080/14767724.2017.1330139

Shankar, V. (2017). A discussion on education outcomes in Budget Private Schools based on data from large-scale assessment studies. In Report on Budget Private Schools in India (pp. 52-59). Delhi: Centre for Civil Society. Retrieved from 
http://ccs.in/sites/default/files/publications/chapter_5_a_discussion_on_education_outco mes_in_budget_private_schools_based_on_data_from_large-scale_assessments_studies.pdf

Singh, R., \& Bangay. C (2014). Low-fee private schooling in India- More questions than answers? Observations from the Young Lives longitudinal study in Andhra Pradesh. International Journal of Educational Development, 39, 132-140. Retrieved from https://doi.org/10.1016/j.ijedudev.2014.08.004

Srivastava, P. (2016). Questioning the global scaling up of low-fee private schooling: The nexus between business, philanthropy, and PPPs. In A. Verger, C. Lubienski \& G. Steiner-Khamsi, World yearbook of education 2016: The global education industry (pp. 248-263). New York: Routledge.

The Global Initiative for Economic, Social and Cultural Rights (GI-ESCR). (2018). Bridge International Academic Investors. GI ECSR Brief. Retrieved from http://globalinitiative-escr.org/wpcontent/uploads/2018/02/List-of-BIA-investors.pdf

Tilak. J. (2016). Public private partnership in education. The head foundation. Discussion Paper Series No. 3/2016. Singapore: The Head Foundation. Retrieved from http://www.headfoundation.org/papers/2016_3)_Public_Private_Partnership_in_Educatio n.pdf

Tooley, J. (2018). A chain of low-cost private schools in England. Policy, 34(2), 13-17. Retrieved from https://www.cis.org.au/app/uploads/2018/06/34-2-tooley-james.pdf

Torche, F. (2005). Privatization reform and inequality of educational opportunity: The case of Chile. Sociology of Education, 78(4), 316-343. https://doi.org/10.1177/003804070507800403

Verger, A., Zancajo, A., \& Fontdevila, C. (2018). Experimenting with educational development: international actors and the promotion of private schooling in vulnerable contexts. In G. Steiner-Khamsi \& A. Draxler (Eds.), The state, business and education public-private partnerships revisited (pp. 16-38). London: Edward Elgar. https://doi.org/10.4337/9781788970334.00007

Walford, G. (2015) The globalisation of low-fee private schools. In: Zajda J. (Eds). Second international handbook on globalisation, education and policy research. Springer, Dordrecht https://doi.org/10.1007/978-94-017-9493-0_18

Weerawardena, J., \& Mort, G. (2006). Investigating social entrepreneurship: A multidimensional model. Journal of World Business, 41(1), 21-35. Retrieved from https://doi.org/10.1016/j.jwb.2005.09.001

Yitshaki, R., \& Kropp, F. (2015). Motivations and opportunity Recognition of social entrepreneurs. Journal of Small Business Management. Retrieved from LUSEM Library website http://www.lusem.lu.se/library. https://doi.org/10.1111/jsbm.12157

Zahra, S., Gedajlovic, E., Neubaum, D., \& Shulman, J. (2009). A typology of social entrepreneurs: Motives, search processes and ethical challenges. Journal of Business Venturing, 24, 519-532. https://doi.org/10.1016/j.jbusvent.2008.04.007 


\section{Appendix 1}

\section{Interview Guide with Low-fee Private School Owners}

Thank you so much for agreeing to participate in the interview today. As explained earlier, this interview is part of our study that looks to understand the motivations of individuals who start lowfee private schools in India. We are not researching your school, but why you wanted to set it up. Our questions will explore your journey in starting these schools. All of our questions are voluntary and you can choose not to answer at any point.

1. Can you tell us a bit about your journey that led you to setting up LFPS? (Probing question: Was there any particular influential family member/Friend who worked in education?)

2. Was there a particular moment that made you decide to set up a LFPS? If so, what was it? What is the goal of your work in setting up LFPS?

3. How aware were you about the LFPS sector and the education sector before you entered this industry? How did you get this information? (Probing question: Do you have an ideology regarding change in the education industry? How does the LFPS industry fit into that?)

4. What motivated you to go specifically into LFPS and not enter public education/set up freebased/donor-based schools?

5. What is the vision of your school and the ultimate purpose behind your organization?

6. Given the mixed evidence on the impact of lfps on student outcomes, what drives you to continue this particular work? Do you have any ethical/moral concerns regarding LFPS? How do you overcome those obstacles?

7. What makes you continue to work in LFPS today? Has your drive changed?

8. Have you ever thought about an exit strategy? Under what circumstances would you give up this role? 


\section{Appendix 2}

\section{Top Level Findings}

\begin{tabular}{|c|c|c|}
\hline $\begin{array}{l}\text { Type of motivator- } \\
\text { Push/Pull }\end{array}$ & Specific motivator & $\begin{array}{l}\text { No. of } \\
\text { owners }\end{array}$ \\
\hline Pull & Present life events: Identified a problem & 6 \\
\hline Pull & Present life events: Interactions with school level stakeholders & 2 \\
\hline Pull & Past life events: personal struggles & 3 \\
\hline Pull & Past life events: Inspired by past teacher/individual & 0 \\
\hline Pull & Past life events: Enjoyed being an educator & 2 \\
\hline Pull & $\begin{array}{l}\text { Awareness since childhood of a need to contribute to society: } \\
\text { Family member }\end{array}$ & 8 \\
\hline Pull & Awareness since childhood: Childhood Ambition & 0 \\
\hline Pull & $\begin{array}{l}\text { Ideology: Parents need to value education- be willing to invest in } \\
\text { children }\end{array}$ & 3 \\
\hline Pull & Ideology: Education should be affordable & 2 \\
\hline Pull & Ideology: Education should be free & 0 \\
\hline Pull & Ideology: Market always works & 0 \\
\hline Pull & $\begin{array}{l}\text { Ideology: Nation development/leadership/socially responsible } \\
\text { citizens }\end{array}$ & 3 \\
\hline Pull & Ideology: Making learning sustainable & 1 \\
\hline Pull & Spiritual imperative & 0 \\
\hline Push & Unemployment & 0 \\
\hline Push & Unhappiness with current role/dissatisfaction & 1 \\
\hline Push & Seeking meaning in life & 1 \\
\hline
\end{tabular}




\section{About the Authors}

\section{Hannah Mond}

hrm2125@,tc.columbia.edu

Hannah is a recent Master of Arts graduate from the International Educational Development program at Teachers College, Columbia University. Her research has focused on low fee private schools and also on teacher pedagogical beliefs.

\section{Poorvaja Prakash}

pp2629@tc.columbia.edu

Poorvaja is a recent Master of Education graduate from the International Educational Development program at Teachers College, Columbia University. Her research has focused on school leadership, teacher motivation and low-fee private schools.

\section{About the Guest Editors}

\section{Brent Edwards Jr.}

University of Hawaíi at Mānoa

brent.edwards@hawaii.edu

http://orcid.org/0000-0003-3955-9525

D. Brent Edwards Jr. is an associate professor of theory and methodology in the study of education at the University of Hawai'i at Mānoa. He has more than 10years of experience as an educator, researcher, and scholar of education policy. In his scholarship, he applies political economy perspectives to (a) the examination of the global governance of education and (b) the origins, spread and effects of global education policies. In particular, Brent focuses on the ways that a range of international organizations affect the politics and processes of policymaking and policy implementation. Geographically, these areas of focus have led to research projects on education in many countries across Latin America, Southeast Asia, and Africa. His recent books include The Trajectory of Global Education Policy: Community-based Management in El Salvador and the Global Reform Agenda and Global Education Policy, Impact Evaluations, and Alternatives: The Political Economy of Knowledge Production (both with Palgrave MacMillan). He also has a forthcoming co-edited special issue of Educational Policy entitled "School choice policy and politics around the globe: Sociological contributions."

\section{Alexander Means \\ University of Hawai'i at Mānoa \\ meansaj@hawaii.edu}

Alexander Means is an assistant professor of educational policy with global perspectives in the Department of Educational Foundations, University of Hawai'i at Mānoa. He is the author most recently of Learning to Save the Future: Rethinking Education and Work in the Era of Digital Capitalism (Routledge, 2018); Educational Commons in Theory and Practice: Global Pedagogy and Politics (Palgrave, 2017); and The Wiley Handbook of Global Education Reform (Wiley-Blackwell, 2018). His research examines educational policy and organization in relation to political, economic, cultural, technological, and social change. 


\section{Globalization, Privatization, Marginalization: Assessing Connections in/through Education education policy analysis archives}

\section{(c) (1) (2)}

Readers are free to copy, display, distribute, and adapt this article, as long as the work is attributed to the author(s) and Education Policy Analysis Archives, the changes are identified, and the same license applies to the derivative work. More details of this Creative Commons license are available at https://creativecommons.org/licenses/by-sa/2.0/. EPAA is published by the Mary Lou Fulton Institute and Graduate School of Education at Arizona State University Articles are indexed in CIRC (Clasificación Integrada de Revistas Científicas, Spain), DIALNET (Spain), Directory of Open Access Journals, EBSCO Education Research Complete, ERIC, Education Full Text (H.W. Wilson), QUALIS A1 (Brazil), SCImago Journal Rank, SCOPUS, SOCOLAR (China).

Please send errata notes to Audrey Amrein-Beardsley at audrey.beardsley@asu.edu

Join EPAA's Facebook community at https://www.facebook.com/EPAAAAPE and Twitter feed@epaa_aape. 


\section{education policy analysis archives editorial board}

Lead Editor: Audrey Amrein-Beardsley (Arizona State University)

Editor Consultor: Gustavo E. Fischman (Arizona State University) Associate Editors: Melanie Bertrand, David Carlson, Lauren Harris, Eugene Judson, Mirka KoroLjungberg, Daniel Liou, Scott Marley, Molly Ott, Iveta Silova (Arizona State University)

\author{
Cristina Alfaro \\ San Diego State University \\ Gary Anderson \\ New York University \\ Michael W. Apple \\ University of Wisconsin, Madison
}

Jeff Bale

University of Toronto, Canada

Aaron Bevanot SUNY Albany

David C. Berliner

Arizona State University

Henry Braun Boston College

\section{Casey Cobb}

University of Connecticut

Arnold Danzig

San Jose State University

Linda Darling-Hammond

Stanford University

Elizabeth H. DeBray

University of Georgia

David E. DeMatthews

University of Texas at Austin

Chad d'Entremont Rennie Center

for Education Research \& Policy

John Diamond

University of Wisconsin, Madison

Matthew Di Carlo

Albert Shanker Institute

Sherman Dorn

Arizona State University

Michael J. Dumas

University of California, Berkeley

Kathy Escamilla

University ofColorado, Boulder

Yariv Feniger Ben-Gurion

University of the Negev

Melissa Lynn Freeman

Adams State College

Rachael Gabriel

University of Connecticut
Amy Garrett Dikkers University

of North Carolina, Wilmington

Gene V Glass

Arizona State University

Ronald Glass University of

California, Santa Cruz

Jacob P. K. Gross

University of Louisville

Eric M. Haas WestEd

Julian Vasquez Heilig California

State University, Sacramento

Kimberly Kappler Hewitt

University of North Carolina

Greensboro

Aimee Howley Ohio University

Steve Klees University of Maryland

Jaekyung Lee SUNY Buffalo

Jessica Nina Lester

Indiana University

Amanda E. Lewis University of

Illinois, Chicago

Chad R. Lochmiller Indiana

University

Christopher Lubienski Indiana

University

Sarah Lubienski Indiana University

William J. Mathis

University of Colorado, Boulder

Michele S. Moses

University of Colorado, Boulder

Julianne Moss

Deakin University, Australia

Sharon Nichols

University of Texas, San Antonio

Eric Parsons

University of Missouri-Columbia

Amanda U. Potterton

University of Kentucky

Susan L. Robertson

Bristol University
Gloria M. Rodriguez

University of California, Davis

R. Anthony Rolle

University of Houston

A. G. Rud

Washington State University

Patricia Sánchez University of

University of Texas, San Antonio

Janelle Scott University of

California, Berkeley

Jack Schneider University of

Massachusetts Lowell

Noah Sobe Loyola University

Nelly P. Stromquist

University of Maryland

Benjamin Superfine

University of Illinois, Chicago

Adai Tefera

Virginia Commonwealth University

A. Chris Torres

Michigan State University

Tina Trujillo

University of California, Berkeley

Federico R. Waitoller

University of Illinois, Chicago

Larisa Warhol

University of Connecticut

John Weathers University of

Colorado, Colorado Springs

Kevin Welner

University of Colorado, Boulder

Terrence G. Wiley

Center for Applied Linguistics

John Willinsky Stanford University

Jennifer R. Wolgemuth

University of South Florida

Kyo Yamashiro

Claremont Graduate University

Miri Yemini

Tel Aviv University, Israel 


\section{archivos analíticos de políticas educativas consejo editorial}

Editor Consultor: Gustavo E. Fischman (Arizona State University)

Editores Asociados: Felicitas Acosta (Universidad Nacional de General Sarmiento, Argentina), Armando Alcántara Santuario (Universidad Nacional Autónoma de México), Ignacio Barrenechea, Jason Beech (Universidad de San Andrés), Angelica Buendia, (Metropolitan Autonomous University), Alejandra Falabella (Universidad Alberto Hurtado, Chile), Veronica Gottau (Universidad Torcuato Di Tella), Antonio Luzon, (Universidad de Granada), José

Luis Ramírez, (Universidad de Sonora), Paula Razquin, Axel Rivas (Universidad de San Andrés), Maria Alejandra Tejada-Gómez (Pontificia Universidad Javeriana, Colombia)

\section{Claudio Almonacid \\ Universidad Metropolitana de \\ Ciencias de la Educación, Chile \\ Miguel Ángel Arias Ortega \\ Universidad Autónoma de la \\ Ciudad de México \\ Xavier Besalú Costa \\ Universitat de Girona, España \\ Xavier Bonal Sarro Universidad Autónoma de Barcelona, España}

Antonio Bolívar Boitia

Universidad de Granada, España

José Joaquín Brunner Universidad

Diego Portales, Chile

Damián Canales Sánchez

Instituto Nacional para la

Evaluación de la Educación,

México

\section{Gabriela de la Cruz Flores}

Universidad Nacional Autónoma de

México

Marco Antonio Delgado Fuentes

Universidad Iberoamericana,

México

Inés Dussel, DIE-CINVESTAV, México

Pedro Flores Crespo Universidad

Iberoamericana, México

\author{
Ana María García de Fanelli \\ Centro de Estudios de Estado y \\ Sociedad (CEDES) CONICET, \\ Argentina \\ Juan Carlos González Faraco \\ Universidad de Huelva, España \\ María Clemente Linuesa \\ Universidad de Salamanca, España \\ Jaume Martínez Bonafé \\ Universitat de València, España
}

Alejandro Márquez Jiménez

Instituto de Investigaciones sobre la

Universidad y la Educación, UNAM, México

María Guadalupe Olivier Tellez, Universidad Pedagógica Nacional, México

Miguel Pereyra Universidad de

Granada, España

Mónica Pini Universidad Nacional de San Martín, Argentina

Omar Orlando Pulido Chaves

Instituto para la Investigación

Educativa y el Desarrollo

Pedagógico (IDEP)

José Ignacio Rivas Flores

Universidad de Málaga, España
Miriam Rodríguez Vargas

Universidad Autónoma de

Tamaulipas, México

José Gregorio Rodríguez

Universidad Nacional de Colombia, Colombia

Mario Rueda Beltrán Instituto de Investigaciones sobre la Universidad y la Educación, UNAM, México

José Luis San Fabián Maroto

Universidad de Oviedo, España

Jurjo Torres Santomé, Universidad de la Coruña, España

Yengny Marisol Silva Laya

Universidad Iberoamericana, México

Ernesto Treviño Ronzón

Universidad Veracruzana, México

Ernesto Treviño Villarreal

Universidad Diego Portales

Santiago, Chile

Antoni Verger Planells

Universidad Autónoma de

Barcelona, España

Catalina Wainerman

Universidad de San Andrés, Argentina

Juan Carlos Yáñez Velazco

Universidad de Colima, México 


\section{arquivos analíticos de políticas educativas conselho editorial}

Editor Consultor: Gustavo E. Fischman (Arizona State University)

Editoras Associadas: Kaizo Iwakami Beltrao, (Brazilian School of Public and Private Management - EBAPE/FGV, Brazil), Geovana Mendonça Lunardi Mendes (Universidade do Estado de Santa Catarina), Gilberto José Miranda, (Universidade Federal de Uberlândia, Brazil), Marcia Pletsch, Sandra Regina Sales (Universidade Federal Rural do Rio de Janeiro)

\author{
Almerindo Afonso \\ Universidade do Minho \\ Portugal \\ Rosanna Maria Barros Sá \\ Universidade do Algarve \\ Portugal
}

\section{Maria Helena Bonilla \\ Universidade Federal da Bahia \\ Brasil}

\section{Rosa Maria Bueno Fischer}

Universidade Federal do Rio Grande

do Sul, Brasil

\section{Alice Casimiro Lopes}

Universidade do Estado do Rio de Janeiro, Brasil

\section{Suzana Feldens Schwertner}

Centro Universitário Univates

Brasil

Flávia Miller Naethe Motta

Universidade Federal Rural do Rio de Janeiro, Brasil

\section{Alexandre Fernandez Vaz \\ Universidade Federal de Santa \\ Catarina, Brasil}

\section{Regina Célia Linhares Hostins \\ Universidade do Vale do Itajaí, Brasil}

Alfredo Macedo Gomes
Universidade Federal de Pernambuco
Brasil

Jefferson Mainardes

Universidade Estadual de Ponta

Grossa, Brasil

Jader Janer Moreira Lopes

Universidade Federal Fluminense e

Universidade Federal de Juiz de Fora, Brasil

\section{Debora Nunes}

Universidade Federal do Rio Grande do Norte, Brasil

\author{
Alda Junqueira Marin \\ Pontifícia Universidade Católica de \\ São Paulo, Brasil
}

\section{Dalila Andrade Oliveira}

Universidade Federal de Minas

Gerais, Brasil
José Augusto Pacheco

Universidade do Minho, Portugal

Jane Paiva

Universidade do Estado do Rio de

Janeiro, Brasil

Paulo Alberto Santos Vieira

Universidade do Estado de Mato

Grosso, Brasil

Fabiany de Cássia Tavares Silva

Universidade Federal do Mato

Grosso do Sul, Brasil

António Teodoro

Universidade Lusófona

Portugal

\section{Lílian do Valle}

Universidade do Estado do Rio de

Janeiro, Brasil

\section{Alfredo Veiga-Neto}

Universidade Federal do Rio Grande do Sul, Brasil 